\title{
SISTEM DESTINASI PARIWISATA DI KABUPATEN BOGOR JAWA BARAT
}

\author{
Firman Syah \\ Institut Ilmu Sosial dan Manajemen Stiami \\ firman_tegal@yahoo.com
}

\begin{abstract}
Abstrak. Sistem destinasi wisata yang ada di Kabupaten Bogor pada dasarnya sudah masuk pada integral pembangunan yang ada, sehingga dapat diakses oleh seluruh dunia. Pengaruh dari konsep pembangunan pariwisata tersebut pada dasarnya meningkatkan percepatan pembangunan dan perekonomian pada wilayah yang cukup besar. Hal ini menyebabkan pembangunan pariwisata di Kabupaten Bogor sebagai salah satu sektor prioritas.

Untuk memperoleh data yang akurat dan terkini, penulis melakukan penelitian secara langsung di lapangan dengan menggunakan metode kualitatif yang secara induktif. Hasil menunjukkan bahwa sistem destinasi wisata yang ada di Kabupaten Bogor dilaksanakan pada dasarnya sudah berjalan sebagaimana mestinya. Namun, jika dibandingkan dengan desa-desa wisata yang ada di luar Kabupaten Bogor misalnya Kabupaten Gunungkidul di Yogyakarta jelas masih kalah jauh.

Kelebihan dan kekurangan yang ada di sistem destinasi wisata tersebut adalah Sistem Informasi Desa (SID) yang belum maksimal seperti keberadaan website terencana sebagaimana sistem yang berjalan di Kabupaten Gunungkidul. Sehingga wisatawan domestik yang berkunjung masih dari wilayah Jakarta, Depok, Tangerang, dan Bekasi. Untuk itu, desa wisata terus melakukan studi banding selain ke Yogyarakata juga ke Cibuntu di Kuningan, termasuk lakukan sertifikasi profesi.
\end{abstract}

Kata Kunci: Sistem Destinasi, Model Destinasi, dan Sistem Informasi Desa.

Abstract. The existing tourist destination system in Bogor Regency basically has entered the integral of existing development, so that it can be accessed by the whole world. The influence of the concept of tourism development basically increases the acceleration of development and economy in a large area. This causes the development of tourism in Bogor Regency as one of the priority sectors.

To obtain accurate and current data, the authors conduct research directly in the field using qualitative methods that are inductive. The results show that the existing tourist destination system in Bogor Regency implemented basically been running as it should. However, when compared with tourist villages outside of Bogor Regency such as Gunungkidul Regency in Yogyakarta obviously still far behind.

The advantages and disadvantages that exist in the tourist destination system is the Village Information System (SID) that has not been maximized as the existence of a planned website as the system that runs in Gunungkidul Regency. So that the visiting domestic tourists are still from Jakarta, Depok, Tangerang, and Bekasi. For that, the village tour continues to conduct comparative studies in addition to Yogyarakata also to Cibuntu in Kuningan, including professional certification.

Keywords: Destination System, Destination Model, and Village Information System

\section{Pendahuluan}

Sistem destinasi wisata yang ada di Kabupaten Bogor pada dasarnya sudah masuk pada integral pembangunan yang ada, sehingga dapat diakses oleh seluruh dunia. Pengaruh dari konsep pembangunan pariwisata tersebut pada dasarnya meningkatkan percepatan pembangunan dan perekonomian pada wilayah yang cukup besar. Hal ini menyebabkan pembangunan pariwisata di Kabupaten Bogor sebagai salah satu sektor prioritas. Akhir-akhir ini, kepariwisataan yang ada di Kabupaten 
Bogor relatif mengalami peningkatan dalam jumlah wisatawan yang melakukan kunjungan. Walau pengembangan pariwisata yang dilaksanakan secara optimal, pada akhirnya memiliki kontribusi yang nyata kepada lingkungan, sosial, ekonomi, dan budaya khususnya terhadap seluruh masyarakat di Indonesia agar dapat merasakan manfaat dari pembangunan di daerah.

Bagaimanapun sistem destinasi wisata di Kabupaten Bogor terjadi karena letak yang termasuk strategis dan memiliki potensi nyata dalam mendukung pertumbuhan ekonomi dan pelayanan. Hal ini merupakan salah satu peluang yang penting dalam menambah pendapatan daerah dibandingkan dengan daerah-daerah lain yang memiliki sistem destinasi wisata tergolong biasa. Program ini termasuk juga untuk mendukung pola kerja destinasi wisata sebagaimana dinyatakan dalam Undang-undang No. 10 Tahun 2009 bahwa pariwisata merupakan berbagai macam kegiatan dan didukung berbagai fasilitas serta layanan yang disediakan oleh masyarakat, pengusaha, pemerintah, dan pemerintah daerah. Artinya, terdapat beberapa wilayah potensial yang ada di Kabupaten Bogor yang dapat dijadikan acuan dalam penerapan sistem destinasi wisata.

Kedekatannya dengan Kota Jakarta dan Kota Bogor juga kabupaten dan kota lain di Jawa Barat destinasi wisata di Kabupaten Bogor ini menjadi sumber pasar wisatawan baik domestik maupun mancanegara yang menjadikan Kabupaten Bogor sebagai salah satu destinasi favorit bagi masyarakat. Bahkan jika ditarik masa silam, Kabupaten Bogor juga menyajikan beberapa destinasi wisata dengan kategori sejarah dan kebudayaan di masa lampau yang cukup penting. Sehingga, Kabupaten Bogor menjadi bagian dari perkembangan atas peninggalan waktu ke waktu yang sampai sekarang ini masih dapat dinikmati oleh masyarakat umum (wisatawan). Oleh karena itu, Kabupaten Bogor sudah seharusnya menata sumber daya untuk dikelola dan dimanfaatkan oleh wisatawan sebagai daya tarik pariwisata. Baik itu sumber daya alam, sumber daya kebudayaan, dan manusia sebagai pelaku pariwisata. Ditambah dengan faktor lain yang menyebabkan wisatawan mudah untuk mengunjungi seperti dukungan fasilitas, transportasi, dan pelayanan pariwisata.

Dengan kalimat lain, sistem destinasi wisata di Kabupaten Bogor tersebut mempunyai daya tarik untuk mengikat wisatawan datang berkunjung. Bahkan mereka dapat menggali lebih destinasi wisata pilihan yang belum tersentuh dan masuk dalam sistem yang mendukung keberlangsungan destinasi wisata di Kabupaten Bogor. Fasilitas yang diberikan oleh pemerintah dan masyarakat selaku stakeholder semestinya menjadi salah satu poin penting dalam pelayanan prima supaya mereka tidak lepas dan pindah untuk mencoba destinasi wisata lain. Uji coba yang dilakukan oleh wisatawan tidak selamanya buruk, karena mereka akan singgah dan memiliki destinasi wisata andalan untuk liburan ketika segala fasilitas yang dibutuhkan sudah tersedia. Salah satunya Kabupaten Bogor. Tentu hal ini dipadukan dengan sistem kepariwisataan yang membuat wisatawan merasa mudah untuk berlibur. Antara lain akomodasi, tempat makan dan minum, serta fasilitas pelayanan umum lain (baik itu telekomunikasi, air, listrik, maupun internet). Atas dasar itulah penulis ingin mengetahui lebih dalam mengenai sistem destinasi wisata yang ada di Kabupaten Bogor dengan perumusan masalah:

1. Bagaimana sistem destinasi wisata yang ada di Kabupaten Bogor?

2. Bagaimana kelebihan dan kekurangan yang ada di sistem destinasi wisata tersebut?

\section{Tinjauan Pustaka}

Dalam memberikan informasi kepariwisataan yang relevan, pemerintah memerlukan suatu media yang dapat membantu mempromosikan sekaligus membantu wisatawan menemukan keindahan dan keunikan yang ada di Kabupaten Bogor. Setelah wisatawan mengetahui secara pasti dan mampu mengenali destinasi wisata unggulan di Kabupaten Bogor, maka pada tahap selanjutnya mereka akan dengan mudah datang 
Firman Syah, Sistem Destinasi Pariwisata Di Kabupaten Bogor Jawa Barat...

berkunjung kembali bahkan memberikan rekomendasi kepada pihak lain. Salah satu media yang dapat membantu mempromosikan dan memberikan informasi yang banyak digunakan oleh masyarakat termasuk destinasi wisata di era sekarang adalah website. Diharapkan peran dari website ini membantu dan menambah pengetahuan untuk semua wisatawan yang membutuhkan informasi layanan publik, terutama di Kabupaten Bogor.

Ada sistem yang menjadikan pariwisata masuk kategori di dalam layanan tersebut. Dimana kehadiran pariwisata sebagai perpaduan berbagai fenomena dan hubungan yang timbul dari interaksi antara wisatawan, industri, pemerintah dan masyarakat. Selain itu, aspek kelembagaan juga berpengaruh dari segi keamanan dan ketertiban dan aspek budaya yang merupakan salah satu daya tarik. Dalam praktiknya, terdapat tiga komponen dasar pembentuk produk pariwisata dan tujuan wisata, yaitu Daya Tarik Wisata (Attraction), Amenitas, dan Aksesibilitas (3A). Daya Tarik merupakan keunggulan yang dimiliki suatu daerah yang dapat digunakan untuk "menjual" daerah tersebut sehingga dapat menarik wisatawan untuk datang untuk melakukan kegiatan wisata. Sementara amenitas adalah kenyamanan yang didukung oleh berbagai kelengkapan sarana dan prasarana pendukung kegiatan pariwisata. Terakhir aksesibilitas adalah jaringan dan sarana prasarana penghubung yang menghubungkan suatu kawasan wisata dengan wilayah lain yang merupakan pintu masuk bagi para wisatawan untuk mengunjungi tempat wisata.

Inti dari pengembangan sistem yang ada di destinasi wisata adalah sebagai hal yang menjadi sorotan utama, daya tarik yang dapat diciptakan, dan pemanfaatan potensi-potensi yang telah lebih dahulu ada pada daerah tersebut seperti keindahan alam. Termasuk juga ketersediaan dari kegiatan pariwisata di lingkungan tersebut. Misalnya pengemasan produk-produk hasil karya masyarakat lokal yang ada di Kabupaten Gunungkidul yang dapat memberikan nilai tambah dan meningkatkan perekonomian masyarakat. Pun bagi masyarakat lokal yang memiliki keahlian lebih dalam mengelola jenis makanan dan jajanan khas daerah bisa membuka pusat oleholeh atau katering yang menyasar pasar wisatawan, khususnya yang mengadakan pertemuan, acara, rapat, dan pelatihan di kawasan ekowisata. Biasanya wisatawan tersebut mengambil momen berkunjung dalam sebuah kegiatan tertentu. Saat semua program kerja tuntas, maka sebelum kembali pulang mereka membeli oleh-oleh khas daerah, termasuk cenderamata yang masuk kategori jasa lain karena hasil karya dari masyarakat lokal.

Dalam pengembangan pariwisata juga terdapat permasalahan lain yang perlu dibenahi. Antara lain adalah akomodasi untuk wisatawan. Kabupaten Gunungkidul diakui masih sangat minim dan membutuhkan industri perhotelan. Karena mayoritas wisatawan yang datang ke Kabupaten Gunungkidul tidak untuk menginap, mereka hanya berlibur dan menikmati alam yang ada sementara untuk tinggal masih memilih Yogyakarta. Alasan yang menjadi dasar adalah Kabupaten Gunungkidul masih belum memiliki investor untuk membangun sarana tersebut. Padahal, jika seluruh destinasi wisata yang ada di Kabupaten Gunungkidul sudah tersedia akomodasi tersebut, maka akan lebih banyak untuk mendatangkan pemasukan. Karena melalui penginapan wisatawan akan lebih lama tinggal di Kabupaten Gunungkidul dan menjadi aset penting untuk membayar jasa atas layanan dari masyarakat lokal.

Untuk sementara model bisnis tersebut dapat dikelola oleh masyarakat lokal untuk meningkatkan pendapatan mereka. Salah satu yang sudah ada adalah Goa Pindul dengan pengembangan homestay, termasuk di Gunung Nglanggran dan Air Terjun Sri Getuk. Artinya, tanpa kehadiran investor di bidang akomodasi bukan lagi persoalan. Karena melalui penguatan masyarakat lokal untuk menyambut para wisatawan sebenarnya memberikan peluang besar dalam kehidupan sehari-hari. Terlebih ketika pemerintah Kabupaten Gunungkidul memberikan support melalui pendidikan dan pelatihan kepada mereka supaya mudah diberikan sertifikasi sehingga wisatawan yang menginap tidak ragu dalam layanan yang diberikan. Walau pembangunan 
dan pengembangan masih bersifat swadaya masyarakat namun pemerintah dapat memaksimalkan peran masyarakat lokal yakni mempermudah izin dari bisnis yang dijalani.

Peluang bisnis lain yang dapat dimanfaatkan oleh masyarakat lokal untuk menjalankan roda perekonomian daerah ekowisata dengan bisnis biro perjalanan wisatawan. Dimana wisatawan diberikan jasa antar hingga kembali ke tempat tinggal, biasanya berbentuk penyewaan mobil. Termasuk memberikan penjelasan (pemandu wisata) seputar ekowisata yang dikunjungi tersebut. Adapula usaha penjualan tiket untuk wisatawan yang ingin masuk rombongan karena tak mengetahui detail lokasi. Biasanya bentuk yang ditawarkan adalah paket wisata untuk bersama-sama menikmati ekowisata di suatu daerah. Karena bersifat paket ada beberapa destinasi lain yang menjadi tujuan untuk didatangi oleh mereka. Terakhir untuk melengkapi industri ekowisata adalah jenis layanan spa, money changer, pengurusan visa dan passport, serta surat izin lain. Seluruhnya sangat dibutuhkan bagi wisatawan, khususnya mancanegara. Untuk itu, masyarakat lokal yang berminat menjadi bagian pelaku usaha tersebut dapat melakukan kerjasama dengan dinas-dinas yang langsung menangani kebutuhan tersebut. Sehingga bukan calo yang berkeliaran dan justru membuat wisatawan mengalami kerugian dari pemberian layanan.

Sebagian wilayah Kabupaten Gunungkidul yang belum memaksimalkan potensi wisata, maka dapat dalam bentuk kegiatan lain. Kecamatan Panggang misalnya dengan mengembangkan sistem peternakan komunal kambing secara bersama-sama. Atau Kecamatan Girisubo mengembangkan persewaan alat-alat untuk hajatan. Seluruh kegiatan tersebut difasilitasi oleh pemerintah untuk menaikkan taraf hidup masyarakat karena dipasarkan ke seluruh wisatawan yang datang untuk satu tujuan di bidang ekonomi kreatif di Kabupaten Gunungkidul. Misalnya pendampingan pengentasan kemiskinan pertama pengembangan untuk tanaman pangan (ketersediaan pangan) untuk masyarakat yang fokus di bidang pertanian. Pengembangan pasar desa terkait produk di kawasan pemasaran cenderamata yang memudahkan wisatawan melakukan kunjungan ke satu daerah untuk mencari ragam kerajinan masyarakat Kabupaten Gunungkidul secara lengkap. Konsep pasar dapat dibangun seperti showroom dengan difasilitasi permodalan melalui UMKM dari pemerintah dan CSR dari perusahaan-perusahaan BUMN dan BUMS. Artinya, kualitas pelayanan sering didefinisikan sebagai pemenuhan keinginan pelanggan bisnis serta ketepatan penyampaian layanan untuk memenuhi harapan pelanggan. Menurut Wyckof dalam Tjiptono (2005) berpendapat bahwa kualitas layanan adalah tingkat keunggulan. Keunggulan diharapkan bisa mengendalikan keunggulan untuk memenuhi keinginan pelanggan. Dengan kata lain, ada dua faktor utama yang mempengaruhi kualitas layanan, layanan yang diharapkan (expected service) dan layanan dirasakan (perceived service).

Menurut Tjiptono (2005), strategi kualitas layanan atau layanan mencakup empat yaitu atribut layanan pelanggan, pendekatan untuk meningkatkan kualitas layanan, faktor biaya, dan sistem umpan balik untuk kualitas layanan pelanggan.

\section{Metodologi Penelitian}

Untuk memperoleh data yang akurat dan terkini, penulis melakukan penelitian secara langsung di lapangan. Adapun lokasi yang dijadikan penelitian adalah Dinas Kebudayaan dan Pariwisata Kabupaten Bogor dengan fokus pada sistem destinasi wisata dan model destinasi wisata dengan menggunakan metode kualitatif yang secara induktif. Analisis data secara induktif ini digunakan karena beberapa alasan. Pertama, proses induktif lebih dapat menemukan kenyataan-kenyataan jamak sebagai yang terdapat dalam data. Kedua, analisis induktif lebih dapat membuat hubungan peneliti-responden menjadi eksplisit, dapat dikenal, dan akuntabel. Ketiga, analisis demikian lebih dapat menguraikan latar secara penuh dan dapat membuat keputusankeputusan tentang dapat-tidaknya pengalihan pada suatu latar lainnya. Keempat, analisis 
Firman Syah, Sistem Destinasi Pariwisata Di Kabupaten Bogor Jawa Barat...

induktif lebih dapat menemukan pengaruh bersama yang mempertajam hubunganhubungan. Kelima, analisis demikian dapat memperhitungkan nilai-nilai secara eksplisit sebagai bagian dari struktur analitik (Moleong, 2012: 10).

Moleong (2012: 9) kembali menjelaskan, dalam penelitian kualitatif, peneliti sendiri atau dengan bantuan orang lain merupakan alat pengumpul data utama dengan menggunakan metode penelitian yang meliputi pengamatan, wawancara dan penelaahan dokumen. Datadata yang akan dikumpulkan berupa kata-kata dan gambar. Senada dengan Moleong (2012), Andi (2010: 15) mengungkapkan bahwa, metode kualitatif sangat mengutamakan manusia sebagai instrumen penelitian, sebab mempunyai adaptabilitas tinggi hingga senantiasa dapat menyesuaikan diri dengan situasi yang berubah-ubah selama penelitian itu. Berdasarkan uraian tersebut dapat dikemukakan secara sederhana, bahwa metode penelitian ini berusaha mendeskripsikan objek penelitian berdasarkan data dan fakta sebenarnya, serta menganalisa melalui konsepkonsep yang telah dikembangkan sebelumnya dengan peneliti sebagai instrumen itu sendiri dalam memecahkan permasalahannya.

Penelitian dilakukan untuk mengidentifikasikan sistem destinasi wisata yang meliputi desa-desa wisata di lingkungan masyarakat Kabupaten Bogor dengan penggalian data seperti:

1. Data primer yang dikumpulkan langsung dari sumber utama. Pertama, angket dalam bentuk pertanyaan tertulis dan dilakukan melalui wawancara langsung kepada Bidang Destinasi Wisata, Kasi Desa Wisata, Dinas Kebudayaan dan Pariwisata Kabupaten Bogor, Asep Tetariana supaya memperoleh gambaran yang jelas mengenai desa-desa wisata. Kedua, observasi lapangan untuk mengetahui kondisi sistem desa wisata yang sudah dilaksanakan.

2. Data sekunder yaitu data internal dan data eksternal dari studi pustaka untuk memperoleh gambaran aspek teoritis yang jelas dengan mengumpulkan bahan-bahan tertulis terkait. Seperti, materi kuliah, buku-buku perpustakaan, surat kabar, jurnal, UU serta tulisan-tulisan lain yang menunjang dan terkait.

Dalam penelitian kualitatif, penulis sendiri menjadi instrumen atau alat penelitian, seperti yang ditulis Nasution (dalam Sugiyono, 2012: 59). Yang menyatakan dalam penelitian kualitatif tidak ada pilihan lain daripada menjadikan manusia sebagai instrumen penelitian utama. Alasannya adalah segala sesuatunya belum mempunyai bentuknya yang pasti. Oleh karena itu, penulis sebagai instrumen harus divalidasi, seberapa jauh penulis siap melakukan penelitian dengan menggunakan teknik wawancara mendalam.

\section{Hasil dan Pembahasan}

Sistem yang berlaku pada destinasi wisata pada dasarnya sudah berjalan sebagaimana mestinya. Dimana, segala informasi yang dibutuhkan oleh wisatawan dapat diperoleh secara lengkap dan detail dari data-data yang terdapat dalam website mengenai pariwisata di Kabupaten Bogor. Namun, jika dibandingkan dengan desa-desa wisata yang ada di luar Kabupaten Bogor misalnya Kabupaten Gunungkidul di Yogyakarta jelas masih kalah jauh. Walau demikian, pemerintah dan masyarakat lokal terus berupaya untuk mengembangkan sistem destinasi wisata yang ada di Kabupaten Bogor. Sehingga menjadi lebih baik dan dapat dengan sempurna menyajikan informasi yang dibutuhkan oleh wisatawan terkait produk destinasi wisata yang menarik. Hal ini bukan menjadi sesuatu hal yang mudah. Karena butuh kerjasama semua pihak untuk dapat memberikan layanan jasa yang memuaskan dan benar-benar ada di Kabupaten Bogor.

Di Gunungkidul seluruh usaha ekonomi kreatif pariwisata berbasis kearifan lokal (ekowisata) sebagai upaya dari masyarakat yang kemudian difasilitasi oleh pemerintah untuk pengembangan lebih lanjut. Artinya, kerjasama yang dijalin bersama-sama di seluruh destinasi wisata yang ada di Kabupaten Gunungkidul dilakukan melalui promosi dengan menggandeng pihak swasta dalam bentuk bantuan CSR sebagai bentuk kepedulian terhadap orang miskin. Termasuk 
membantu pembangunan karakter masyarakat melalui pendidikan dan kesehatan. Bantuanbantuan yang datang tersebut diharapkan menyebar ke seluruh sektor di Kabupaten Gunungkidul. Selanjutnya perlu ada perbaikan data kemiskinan di Kabupaten Gunungkidul supaya menjadi acuan bagi stakeholder dalam melanjutkan pembangunan. Hal ini bisa menggunakan Sistem Informasi Desa (SID) yang sudah ada dan terus diperbaiki sesuai perkembangan di lapangan. Konsep tersebut juga menjadi sarana untuk memutuskan sebuah program yang tepat bagi masyarakat.

Bahkan, sistem yang berjalan di Kabupaten Gunungkidul saat ini sedang dirancang bersama semua pihak yang terlibat dalam pembuatan sistem guna memenuhi kebutuhan pariwisata. Dimana ada unsur Bappeda, Dinas Komunikasi dan Informasi, dan Dinas Pariwisata yang mengembangkan sistem online, mengingat di hari-hari tertentu Kabupaten Gunungkidul penuh oleh wisatawan sampai tak mampu menampung wisatawan yang datang. Dengan sistem online tersebut, seluruh pihak yang berkepentingan dapat mengetahui secara detail berapa banyak destinasi wisata, pada jam berapa bisa masuk lokasi, dan terutama daya tampung masingmasing destinasi wisata. Juga ragam cenderamata yang disediakan dan dijual kepada wisatawan, apalagi sudah ada wisatawan asal mancanegara sebanyak 3\% hingga 5\% yang datang dari Cina, Korea, Jepang, dan Eropa. Sistem online di Kabupaten Gunungkidul yang sudah terintegrasi dengan baik dan lengkap menghasilkan informasi detail mengenai ekowisata unggulan. Ini juga menjadi alternatif komunikasi pemasaran ekowisata ke semua pihak baik di dalam maupun luar negeri untuk mengetahui potensi di Kabupaten Gunungkidul. Diharapkan muncul rasa ingin tahu dan berminat melakukan kunjungan.

Sementara untuk di Kabupaten Bogor diakui masih minim wisatawan dari mancanegara. Dari 8 juta wisatawan baru sekitar 5000 pengunjung yang berstatus warga negara asing dengan didominasi oleh Timur Tengah. Namun, melalui konsep evaluasi yang sedang digalakkan maka wisatawan terus berdatangan sehingga mampu memaksimalkan potensi yang ada di destinasi wisata Kabupaten Bogor. Terutama memasuki Juni hingga September yang menjadi musim kunjungan wisatawan asal Timur Tengah karena masa libur. Dilihat dari lama tinggal di Kabupaten Bogor, wisatawan mancanegara ini tergolong baik yaitu antara 7 hingga 10 hari. Bahkan perputaran uang di dua desa sangat baik. Terbukti, di dua desa salah satunya Tugu Utara beberapa waktu lalu masyarakat lokal yang menjual jasa pertukaran uang sempat menghitung untuk 16 money changer yang ada jika ditotal secara keseluruhan untuk satu hari penuh mencapai nilai Rp 3 miliar.

Artinya, sudah muncul geliat dari wisatawan mancanegara untuk melirik destinasi-destinasi wisata yang ada di Kabupaten Bogor. Peluang tersebut sangat baik dalam membangkitkan dan mengembangkan potensi yang ada di desa-desa wisata dalam rangka menjual jasa kepada wisatawan. Oleh karena itu, sudah seharusnya pemerintah mensupport masyarakat lokal untuk lebih aktif dalam menjual keunikan-keunikan pariwisata di desa wisata yang tersebar di Kabupaten Bogor. Konsep inilah yang kemudian harus dikembangkan untuk memperoleh lebih banyak wisatawan mancanegara selain juga menyasar wisatawan domestik yang tidak hanya datang dari wilayah Jakarta, Depok, Tangerang, dan Bekasi. Namun juga bisa mendatangkan wisatawan dari luar wilayah tersebut karena mendengar, penasaran, atau sudah beberapa kali datang ke destinasi wisata di Kabupaten Bogor.

Dengan demikian, pola ekonomi kreatif yang dimainkan oleh masyarakat lokal harus terus bersanding dengan kenyataan sebagai 'penjual' jasa kepada wisatawan. Untuk dapat memperkuat posisi masyarakat lokal di Kabupaten Bogor, ada beberapa hal terkait sistem yang perlu dikembangkan lebih dalam. Langkah ini bisa mencontoh pada konsep Kabupaten Gunungkidul yang sedang mencari tahu keunikan dari pariwisata bernuansa kearifan lokal. Konsep pemberdayaan masyarakat lokal yang ada di Kabupaten 
Firman Syah, Sistem Destinasi Pariwisata Di Kabupaten Bogor Jawa Barat...

Gunungkidul setiap tahun diusahakan dapat menurunkan angka kemiskinan di beberapa lokasi wisata. Bahkan setiap Sabtu dan Minggu seluruh destinasi wisata di Kabupaten Gunungkidul bisa mengalami kemacetan hingga 2 jam karena satu hari kedatangan bus mencapai ratusan, belum termasuk mobil dan sepeda motor. Walau banyak kesamaan untuk destinasi wisata namun masing-masing memiliki ciri khas yang dapat dijual oleh masyarakat. Tentunya pemerintah dan perusahaan BUMN dalam hal ini memberikan support melalui pelatihan, CSR, juga sarana prasarana dengan melakukan koordinasi dinasdinas terkait. Kunjungan wisatawan juga di luar target, laporan terakhir pada 2015 dicanangkan 2 juta wisatawan yang datang melebihi angka tersebut.

Padahal, secara kualitas pendidikan Kabupaten Gunungkidul masih tertinggal dari Kabupaten Bogor. Dimana, yang masih menjadi perhatian bagi pemerintah di Kabupaten Gunungkidul adalah perguruan tinggi yang tergolong miskin. Padahal, keberadaan perguruan tinggi bidang kepariwisataan dapat mendukung destinasi wisata, yakni membantu pemberdayaan masyarakat. Hingga kini Kabupaten Gunungkidul masih mencari dan mengajak pihak-pihak yang siap membangun perguruan tinggi untuk bekerjasama dalam pengembangan ekowisata sebagai solusi riil untuk masyarakat. Terlebih ekowisata membuahkan hasil maksimal untuk kehidupan masyarakat lokal yang lebih baik dalam jangka waktu yang lama saat dikelola secara tepat. Dan ini sudah dimiliki oleh Kabupaten Bogor dengan adanya beberapa perguruan tinggi. Artinya, peluang untuk memaksimalkan potensi sistem destinasi wisata pada prinsipnya sudah ada. Tinggal bagaimana model pengelolaan yang dapat dilakukan untuk menjembatani semua kepentingan stakeholder baik pemerintah maupun masyarakat.

Jika dikaji lebih dalam, usaha pengembangan kepariwisataan yang dilaksanakan oleh pemerintah sudah baik. Dimana beragam fasilitas melalui kegiatan terus diselenggarakan supaya masyarakat lokal memiliki kemampuan dalam mengelola destinasi wisata. Antara lain dengan memberikan pelatihan kepada SDM yang menangani wisatawan dan mengelola destinasi wisata. Untuk setiap tahun, pemerintah Kabupaten Bogor selalu mengadakan pelatihan untuk mendirikan usaha tani. Termasuk berbagai pelatihan yang bernuansa manajemen, pelatihan bagaimana pengelolaan homestay, pelatihan bagaimana membuat kemasan kuliner makan minum bagi wisatawan, pelatihan bagaimana membuat paket-paket wisata yang menarik untuk wisatawan, juga jadi tour guide yang dibutuhkan oleh wisatawan. Seluruh program sengaja dimaksimalkan dan dicoba untuk diadakan secara komprehensif. Bahkan sudah beberapa perguruan tinggi yang mencoba membantu untuk mengembangkan destinasi wisata yang ada di Kabupaten Bogor. Konsep yang selalu terbuka tersebut memungkinkan banyak pihak akademisi yang turun lapangan dan menggandeng Dinas Kebudayaan dan Pariwisata sebagai pendamping ideal dalam pengembangan desa-desa wisata. Misalnya untuk pengembangan desa wisata di wilayah puncak sudah ada STP Trisakti, untuk pengembangan lingkungan Desa Tamansari juga dari pihak STP Trisakti, termasuk beberapa lokasi yang dipegang oleh IPB.

Bentuk dukungan yang diberikan pemerintah kepada masyarakat lokal adalah untuk mengembangkan konsep wirausaha. Itulah yang menjadi satu-satunya pilihan saat ini dengan memanfaatkan pariwisata yang berbasis ekowisata dengan mengkombinasikan keahlian masyarakat lokal. Artinya, ada kesempatan yang diberikan oleh pemerintah untuk membangun desa wisata sekaligus diberikan kesempatan mengembangkan diri dengan kebebasan mencari keuntungan sebesar-besarnya dari usaha yang dijalankan. Termasuk juga membuka kesempatan bagi masyarakat lain untuk ikut bekerja (peluang membuka kesempatan/lapangan kerja) yang mana kondisi saat ini banyak pengangguran. Dengan kondisi seperti ini, seperti yang terjadi di Kabupaten Gunungkidul adalah sangat membantu masyarakat lokal untuk mengentaskan kemiskinan sekaligus 
membantu tugas pemerintah dalam rangka meminimalisir angka pengangguran.

Contohnya kongkrit yang dapat dilaksanakan adalah Karangmojo (Goa Pindul) untuk menjadi kawasan wisata. Dimana masyarakat menjadi berdaya saing dari semula tak berdaya secara perekonomian. Sehingga pendapatan per kapita di Goa Pindul menjadi naik dan otomatis kemiskinan menurun. Apalagi terdapat wisata lain selain Goa Pindul. Misal Gunung Nglanggran, Bukit Sriten, Air Terjun Sri Getuk, Green Village, Pantai Baron, Pantai Pulangsawal/ Indrayanti, Pantai Siung, Pantai Ngobaran, Pantai Nampu, Pantai Nguyaan, Pantai Ngedan, Pantai Gesing, dan lain-lain. Walau beragam pilihan pantai terdapat di Kabupaten Gunungkidul, namun masing-masing memiliki view yang berbeda dan ada ciri khas. Nampu misalnya, bisa melihat snorkeling. Ada pula pantai yang bisa melihat air terjun di laut. Kegiatan ekonomi kreatif yang dibangun masyarakat bermula dengan mulai membuka akses untuk wisatawan serta Pemerintah Daerah Gunungkidul memberikan fasilitas dengan pelatihan dan pembentukan Kelompok Sadar Wisata (Pokdarwis).

Pemerintah Kabupaten Bogor juga memberikan peluang yang besar kepada masyarakat di desa-desa dengan potensi wisata untuk belajar (studi banding) ke daerah di luar Kabupaten Bogor. Tahun lalu perwakilan dari desa-desa wisata yang ada di Kabupaten Bogor dikirim ke Yogyakarta. Melalui studi banding tersebut, diharapkan masyarakat memahami segala aspek yang harus diperhatikan dalam membangun dan mengembangkan desa wisata. Sekaligus di bidang manajemen pengelolaan destinasi wisata yang saat ini lebih ke arah sistem informasi. Sehingga, beberapa waktu ke depan desa-desa wisata dapat meniru bahkan bisa melebihi dalam hal kemajuan dan pengembangan yang baik. Untuk itu, konsentrasi masyarakat lokal harus tetap fokus untuk menyukseskan segala bentuk kegiatan yang membangun hasil kerjasama pemerintah dan masyarakat lokal untuk menyambut wisatawan. Bahkan konsep saling terbuka di antara kedua belah pihak itu harus diajukan ke
Dinas Kebudayaan dan Pariwisata supaya segala program kerja desa wisata bisa lebih terarah. Sementara untuk tahun ini sebanyak 30 peserta melakukan studi banding ke Desa Wisata Cibuntu di Kuningan.

Diakui, berwisata ke Kabupaten Kuningan tidak lengkap rasanya jika tidak mengunjungi Desa Wisata Cibuntu. Sebuah desa wisata yang termasuk unik, karena di lingkungan desa banyak ditemukan situs-situs purbakala. Desa ini masuk ke Kecamatan Pasawahan, Kabupaten Kuningan dan berbatasan langsung dengan Kabupaten Cirebon. Konon desa tersebut sudah ada sejak zaman batu (Megalitikum). Hal ini terlihat dari jejak yang masih ada berupa kuburan batu dan masuk dalam situs purbakala di Kabupaten Kuningan. Berada di ujung Barat Kabupaten Kuningan, desa ini persis berada di lereng Gunung Ciremai. Sehingga tak mengherankan, jika udara di desa ini sangat sejuk dan menyegarkan. Tanaman hijau menjadi pemandangan khas di kawasan desa wisata ini. Belum lagi keramahan warga desa yang menyapa setiap wisatawan yang datang sehingga merasa betah dan berminat berlamalama tinggal di desa tersebut. Saat memasuki gerbang Desa Wisata Cibuntu, wisatawan akan disambut $\mathrm{Ki}$ Lengser yang disiapkan untuk menyambut tamu layaknya menyambut rombongan pengantin pria yang akan meminang pengantin perempuan. Diiringi gamelan dan musik angklung, Ki Lengser menari dengan lincah diikuti dua orang pembawa payung. Mereka membawa wisatawan ke tanah lapangan yang dipasangi tenda dan disiapkan minuman khas Desa Cibuntu, yakni jasreh (jahe sareng sereh). Minuman ini adalah minuman welcome dinner yang sengaja disuguhkan warga desa kepada para pengunjung.

Situs-situs yang ada di Desa Wisata Cibuntu tersebut kebanyakan situs kuburan batu pada zaman megalitikum. Dari dalam kuburan batu itu banyak ditemukan kapak genggam yang terbuat dari batu. Kini kapak batu tersebut disimpan di Museum Cipari. Situs-situs purbakala banyak ditemukan di pekarangan rumah penduduk. Namun ada pula 
Firman Syah, Sistem Destinasi Pariwisata Di Kabupaten Bogor Jawa Barat...

yang jauh dari pemukiman warga. Keberadaan situs-situs tersebut tidak mengganggu aktivitas penduduk setempat. Justru sebaliknya, situssitus tersebut dipelihara dengan baik, bahkan ada beberapa di antara warga yang menjadi juru pelihara. Situs-situs tersebut antara lain Ada Situs Bujal Dayeuh, Hulu Dayeuh, Sahurip Kaler, Sahurip Kidul, Cikahuripan, dan Curug Bongsreng. Ditambah lagi adanya mata air yang masih terjaga di desa tersebut. Membuat banyak daya tarik wisatawan yang ingin melakukan kunjungan. Sehingga kehadiran situs-situs tersebut memberikan manfaat bagi masyarakat dan menjadi desa wisata.

Untuk wisatawan yang kebetulan ingin menikmati beberapa hari di Desa Wisata Cibuntu, disediakan beberapa atraksi. Antara lain sepeda gunung, agrowisata, wisata bejarah, dan ketika ingin bermalam maka wisatawan dapat menginap di homestay, sekaligus dapat menikmati berbagai macam kuliner khas Desa Wisata Cibuntu. Ketika wisatawan merasa lelah berkeliling Desa Wisata Cibuntu, maka dapat meminum secara langsung Air Cikahuripan. Air yang berwarna bening, dingin, dan segar ini pun diminati hampir seluruh wisatawan yang datang. Minimal wisatawan akan mandi atau membasuh muka untuk menikmati kesejukan air. Bagi wisatawan yang penasaran ke Desa Wisata Cibuntu dapat ditempuh dengan rute Cirebon - Sumber (Plangon) - Mandirancan Paniis- Cibuntu dengan jarak tempuh $\pm 30 \mathrm{KM}$ dengan jalan yang lumayan berliku. Dan ternyata bukan perwakilan dari warga desa wisata yang ada di Kabupaten Bogor saja yang penasaran dengan Desa Wisata Cibuntu. Namun, adapula 10 penggiat Pokdarwis dan tenaga pendamping desa wisata di Purbalingga juga mengikuti peningkatan kapasitas sumber daya manusia ke Desa Wisata Cibuntu.

Selain keindahan alam dan peninggalan budaya, daya tarik wisata yang lain adalah rumah-rumah penduduk yang terpisah dari ternak. Bahkan, kandang ternak yang terpisah dan tertata rapi dijadikan sebagai salah satu daya tarik wisata edukasi beternak kambing. Dimana pihak desa membuat peraturan yang melarang warga memelihara ternak di sekitar rumah. Intinya, keramahan yang disiapkan masyarakat lokal dalam penyambutan wisatawan jelas-jelas sangat dirasakan, karena memang masyarakat Desa Wisata Cibuntu yang terbuka terhadap wisatawan. Bahkan ada keinginan untuk bisa lebih maju dan mampu menjadi desa wisata terbaik di Indonesia. Salah satu layanan yang diberikan dalam bentuk pengarahan dan panduan terbaik dari kepala desa. Daya tarik lain ketika ada beberapa upacara setempat dalam rangka tertentu seperti sedekah bumi. Sedekah bumi merupakan suatu prosesi adat yang merupakan bentuk ucapan syukur warga terhadap hasil bumi dan juga untuk menghormati 'budak angon'. Sebelum prosesi sedekah bumi diselenggarakan, pagi hari para wisatawan diajak untuk berkeliling desa dan mengenal desa melalui pengairan dan bercocok tanam padi langsung di sawah. Kegiatan ini merupakan kegiatan yang dapat meningkatkan keakraban bagi seluruh peserta tur yang ikut. Wisatawan pun diajak langsung turun ke sawah untuk membajak dan mengetahui cara dalam bertanam padi. Termasuk berjalan kaki di pematang sawah yang bergelimang lumpur sawah adalah pengalaman yang cukup menarik dalam mengawali pagi di Desa Wisata Cibuntu.

Sedekah bumi diawali dengan kelompok arak-arakan masyarakat Desa Wisata Cibuntu yang membawa tetenong. Sesampai di lapangan, seluruh tetenong dikumpulkan dan kemudian acara sedekah bumi dimulai dengan pembukaan doa dan kata sambutan dari beberapa petinggi Desa Wisata Cibuntu, petinggi Kecamatan Pasawahan, dan Bupati Kabupaten Kuningan. Acara penutupan dilakukan dengan penandatanganan batu tulis yang menandakan bahwa Desa Cibuntu resmi menjadi salah satu Desa Wisata Indonesia. Setelah prosesi acara sedekah bumi selesai, para warga kembali ke rumah masing-masing dan membawa tetenong yang berisikan masakan yang sudah dibagi dengan rata dengan warga lain. Selanjutnya para wisatawan yang sudah kenyang mencicipi masakan warga asli melanjutkan perjalanan mengelilingi Desa Wisata Cibuntu ditemani dengan pemandu wisata desa secara ramah. 
Dengan demikian, segala usaha yang dilakukan pemerintah Kabupaten Bogor sudah sesuai dengan capaian untuk keberhasilan dalam meraih kemajuan destinasi wisata. Terlebih saat ini desa-desa wisata yang tersebar di Kabupaten Bogor sudah memiliki paket perjalanan wisata yang dikemas secara profesional bagi wisatawan. Artinya ada kesiapan khusus dalam menyambut wisatawan yang datang untuk dapat diperkenalkan potensi-potensi yang ada di masing-masing desa wisata. Hanya saja kekurangan yang ada di bidang promosi adalah website yang dimiliki untuk desa wisata. Kebetulan hingga saat ini materi pariwisata seputar desa wisata masih masuk ke dalam website Dinas Kebudayaan dan Pariwisata. Namun, untuk media sosial seperti Facebook sudah menjalankan fungsinya untuk melakukan kegiatan pemasaran dan komunikasi antar desa wisata, yaitu Forum Desa Kabupaten Bogor.

Kerjasama antara pemerintah dengan masyarakat lokal juga dapat dilakukan dengan serius. Seperti jika kita melihat Desa Wisata Jampang di Parung. Sebagai pihak yang mensupport adalah Dompet Dhuafa dengan alasan lokasi yang berdekatan dan membuat sebuah perubahan hingga menjadi desa yang maju, termasuk dari segi pembiayaan sehingga pengelolaan dan segala bentuk kegiatan kepariwisataan untuk masyarakat sudah terlaksana. Maksudnya, walau posisi saat ini sudah ada konsep untuk saling mendukung, artinya harus dikembangkan lebih luas sehingga wisatawan pun semakin banyak berdatangan. Ambil contoh yang terjadi di Kabupaten Gunungkidul. Kedua pihak bersama-sama bergandeng tangan untuk mengembangkan potensi yang ada. Dimana investor yang datang dari pihak swasta lokal seperti Pertamina di Ngranggan membantu masyarakat lokal melalui CSR untuk mengembangkan keahlian dalam bentuk pelatihan. Selain itu untuk menggiatkan aktivitas masyarakat, pemerintah memfasilitasi sarana prasarana dalam bentuk jalan, perbankan, rumah sakit, keamanan, pendidikan, air minum, listrik, dan lain-lain dengan melakukan koordinasi bersama dinas terkait.

Pola ini diawali dengan Musyawarah Perencanaan Pembangunan Desa (Musrenbangdes) dan tahap akhir masuk ke tahap rencana pembangunan daerah baik pendek, menengah, atau panjang yang disusun dan dilaksanakan oleh lembaga teknis terkait. Setiap tahun kegiatan pengembangan destinasi wisata terus dilaksanakan oleh pemerintah daerah Kabupaten Gunungkidul. Karena saat ini destinasi wisata yang ada di Kabupaten Gunung Kidul menjadi ikon dan sudah masuk prioritas utama pembangunan dan pengembangan dengan visi utama meningkatkan ekonomi Gunung Kidul melalui wisata. Artinya, Kabupaten Gunungkidul telah memberlakukan wisata berbasis kearifan lokal atau biasa disebut dengan ekowisata. Hal ini dapat diamati dari ragam potensi yang tersedia di Kabupaten Gunungkidul dan kemudian dikelola oleh masyarakat lokal untuk kepentingan bersama. Sehingga masyarakat mampu hidup dengan lebih baik melalui usaha yang sudah dibangun sejak menjadi destinasi wisata. Langkah selanjutnya tinggal mengemas produk yang sudah tersedia menjadi lebih menarik dan mendapat perhatian besar dari wisatawan. Tentu dibutuhkan keahlian dari masing-masing pelaku usaha dan inovasi untuk mempromosikan lebih luas ke wisatawan yang dituju sebagai salah satu program mendatangkan pendapatan. Seiring berjalannya waktu, ekowisata yang diperhatikan justru membawa lingkungan dan masyarakat setempat di Kabupaten Gunungkidul menjadi lebih maju. Bahkan, dapat membuka lapangan pekerjaan bagi seluruh lapisan masyarakat yang tidak memiliki pendapatan tetap. Hal ini dilakukan untuk mencegah mereka keluar kampung dan mengadu nasib ke beberapa kota besar.

Sementara untuk Kabupaten Bogor, kondisi pengembangan masih dilaksanakan oleh pemerintah daerah yakni dengan menyusun Rencana Induk Pengembangan Pariwisata Daerah (RIPARDA). Walau konsep tersebut sudah baik, namun ke depan tetap harus mengutamakan masing-masing desa 
Firman Syah, Sistem Destinasi Pariwisata Di Kabupaten Bogor Jawa Barat...

untuk menyusun program secara mandiri, karena merekalah yang mengetahui kebutuhan untuk kepariwisataan. Untuk itu di setiap tahun pihak Dinas Kebudayaan dan Pariwisata senantiasa melakukan evaluasi, termasuk menetapkan target untuk tahun yang akan datang. Misalkan pada 2016 target kita 5 juta sekian, ternyata laporan yang masuk justru mencapai 8 juta. Artinya untuk periode 2017 dilakukan revisi target dengan menaikkan lagi jumlah wisatawan untuk 2017. Sejatinya jumlah wisatawan yang mencapai 8 juta di 2016 itu hanya yang benar-benar membeli dan berdasarkan tiket yang dijual oleh pelaku objek wisata. Belum menghitung wisatawan yang datang hanya menikmati kesejukan dan pulang kembali. Bersyukur Kabupaten Bogor di bidang kepariwisataan sudah berkembang, karena ini menjadi salah satu sektor yang yang diandalkan dalam perekonomian Kabupaten Bogor.

Oleh karena itu, harus ada strategi pemasaran yang jelas seperti dilaksanakan oleh Kabupaten Gunungkidul supaya lebih unggul dari destinasi wisata lain juga terkait beberapa hal. Mengingat aktivitas tersebut membantu perekonomian masyarakat, maka salah satu upaya yang menjadi prioritas pengembangan adalah dengan anggaran dan kebijakan politis yang lebih mendukung keberadaan destinasi wisata di Kabupaten Gunungkidul. Sementara dari segi promosi yang sudah dilaksanakan melalui peran aktif masyarakat yang tergabung dalam Pokdarwis dan memanfaatkan website dalam rangka memperluas pasar sekaligus memperkenalkan destinasi wisata unggulan Gunungkidul. Sedangkan dari pemerintah seperti Bappeda Kabupaten Gunungkidul menganjurkan instansi dari luar ketika ada kegiatan di Gunungkidul wajib mampir ke destinasi wisata yang ada. Perubahan drastis mata pencaharian juga terlihat dari mayoritas sebagai buruh tani maka sekarang beralih ke pelayanan jasa yang bersertifikasi supaya wisatawan bisa lebih betah ketika tinggal di Kabupaten Gunungkidul. Strategi mendatangkan wisatawan dalam jumlah besar tersebut pada dasarnya memiliki dampak positif bagi masyarakat lokal.
Karena itulah, ada kenyataan yang diperoleh dari kegiatan ekonomi kreatif ini, angka kemiskinan yang dievaluasi oleh pemerintah memiliki ukuran relatif menurun. Walau beberapa waktu belakangan yang belum masuk evaluasi Kabupaten Gunungkidul yakni secara makro mengalami kenaikan. Melihat perkembangan dari tahun ke tahun mulai 2011 hingga 2015 mencapai $20,01 \%$ dan pada 2016 mengalami kenaikan menjadi 20,09\%. Angkaangka tersebut belum dilakukan evaluasi dan tidak hanya terjadi di Kabupaten Gunungkidul, karena di luar juga terjadi kenaikan. Intinya kegiatan yang paling pokok untuk membantu masyarakat lokal di lingkungan destinasi wisata Kabupaten Gunungkidul adalah ekonomi kreatif. Yaitu, pendapatan secara kontinyu dan bukan lagi bersifat intervensi. Sebelumnya, jika masyarakat lokal memiliki pemasukan dari bantuan pemerintah dalam bentuk stimulus terkait kebijakan seperti BLT, bedah rumah, dan lain-lain. Maka, saat ini kebijakan Kabupaten Gunungkidul mampu membawa arah ekonomi masyarakat menjadi lebih baik masih terus dibenahi dan dicari formula yang tepat.

Bappeda sebagai lembaga pemerintah di sektor kebijakan perencanaan mengutamakan program pengentasan kemiskinan dengan sistematis. Oleh karena itu, program kemiskinan masuk ke dokumen perencanaan, kemudian mempunyai tanggung jawab untuk memasukkan program kerja di dalam dokumen perencanaan, dan secara teknis harus mengawal untuk diterjemahkan ke dalam rencana kerja masing-masing organisasi perangkat daerah yang secara teknis untuk diterjemahkan ke dalam satu program. Hasil dari dukungan pemerintah Kabupaten Gunungkidul melalui pembangunan dan pengembangan destinasi wisata mempunyai dampak baik dalam perekonomian daerah Kabupaten Gunungkidul. Semua destinasi wisata di Kabupaten Gunungkidul mulai booming pada 2013. Terlihat dari kunjungan wisatawan menuju destinasi yang ada di Kabupaten Gunungkidul hanya ribuan sekarang sudah mencapai jutaan dalam kurun waktu 4 tahun. Bahkan mayoritas masyarakat lokal di Kabupaten Gunungkidul memiliki 
mata pencaharian dalam hal pelayanan jasa. Sebelumnya mereka memiliki usaha sebagai buruh tani. Karena bersifat layanan jasa, maka mata pencaharian dari sebuah destinasi wisata perlu didukung dari beragam aspek. Salah satunya aspek cenderamata yang memiliki ciri khas dari suatu daerah. Antara lain produk oleh-oleh yang berasal dari kerajinan masyarakat lokal seperti kaos atau pernak pernik yang diminati wisatawan. Bisa pula cenderamata rasa yang berasal dari kuliner masyarakat lokal dan belum tentu dibuat oleh masyarakat lain. Mengingat ada beberapa rempah-rempah menjadi bumbu yang memberikan cita rasa kuliner.

Memang langkah yang tepat untuk melaksanakan kegiatan tersebut adalah melalui sertifikasi bagi para SDM di desa-desa wisata. Hal ini dilakukan oleh Kabupaten Bogor dengan mengambil model sertifikasi yang mengarah ke akomodasi, pegawai hotel,

Dari pembahasan di atas, dapat disimpulkan bahwa:

1. Sistem destinasi wisata yang ada di Kabupaten Bogor dilaksanakan pada dasarnya sudah berjalan sebagaimana mestinya. Dimana, segala informasi yang dibutuhkan oleh wisatawan dapat diperoleh secara lengkap dan detail dari data-data yang terdapat dalam website mengenai pariwisata di Kabupaten Bogor. Namun, jika dibandingkan dengan desa-desa wisata yang ada di luar Kabupaten Bogor misalnya Kabupaten Gunungkidul di Yogyakarta jelas masih kalah jauh. Walau demikian, pemerintah dan masyarakat lokal terus berupaya untuk mengembangkan sistem destinasi wisata yang ada di Kabupaten Bogor.

2. Kelebihan dan kekurangan yang ada di sistem destinasi wisata tersebut adalah Sistem Informasi Desa (SID) yang belum maksimal seperti keberadaan website terencana sebagaimana sistem yang berjalan di Kabupaten Gunungkidul. Sehingga wisatawan domestik yang berkunjung masih dari wilayah Jakarta, Depok, Tangerang, dan Bekasi. Untuk itu, desa-desa wisata terus melakukan restoran, tour guide sejak 2015. Namun, sebelum diikutkan sertifikasi, mereka dibekali materi oleh pemerintah supaya memahami layanan jasa secara utuh. Langkah selanjutnya diuji hasil pelatihan dan jika menurut para penguji internal sudah memumpuni, barulah dikirim ke LSP yang menangani sertifikasi. Tahun ini kita sudah mengirimkan 40 orang untuk disertifikasi dan masalah lulus atau tidak itu menjadi kewenangan LSP. Kalau menurut LSP belum layak disertifikasi ya harus diterima dan jika ingin mengikuti program sertifikasi ulang diperbolehkan untuk tahun depan. Sejak 2015, sudah ada ratusan yang disertifikasi. Jika per model ada 30 orang yang lulus dikalikan 3 model artinya ada 120 orang yang sudah disertifikasi dalam satu tahap. Belum untuk tahap berikutnya di tahun yang sama.

\section{Kesimpulan dan Saran}

studi banding salah satunya selain ke Yogyarakata juga ke Desa Wisata Cibuntu di Kuningan, termasuk dalam hal sertifikasi profesi.

Saran yang disampaikan oleh peneliti adalah:

1. Pemerintah daerah dan pemerintah desa selaku stakeholder harus memberikan ruang gerak yang bebas kepada masyarakat untuk berkreativitas dalam usaha membangun desa wisata.

2. Dukungan yang diberikan kepada masyarakat di desa wisata perlu berkesinambungan dan terus menerus namun tetap melakukan tahap monitoring dan evaluasi sehingga tidak berjalan stagnan.

3. Masyarakat dituntut lebih proaktif dalam rangka mengapresiasikan diri agar keluar dari kemiskinan dan pengangguran melalui kerja nyata di lingkungan sendiri.

\section{Daftar Pustaka}

Andi, Prastowo. (2010). Menguasai TeknikTeknik Koleksi Data Penelitian Kualitatif. Yogyakarta: Diva Press. 
Firman Syah, Sistem Destinasi Pariwisata Di Kabupaten Bogor Jawa Barat...

Moleong, Lexy J. (2012). Metodologi Penelitian Kualitatif. Bandung: Remaja Rosdakarya.

Sugiyono. (2012). Metodologi Penelitian Bisnis. Cetakan Kelima Belas. Bandung: Alfabeta.
Tjiptono, Fandy. 2005. Pemasaran Jasa. Jakarta: Bayumedia Publishing.

Undang-undang No. 10 Tahun 2009. Tentang Kepariwisataan. 